\title{
THE HISTORY OF MEDICINE IN NEW ZEALAND
}

by

\author{
SIR ARTHUR PORRITT, BT.
}

IT Is almost one hundred years ago since my father was born in New Zealand-justas it had taken his parents the best part of five months to sail out from England, to that lovely and stimulating Colony. For fifty of the eighty years he lived, he practised medicine in New Zealand-after qualifying and obtaining his Fellowship in Edinburgh. This medicine, at the turn of the century and later, was the best form of general practice; it included surgery and much obstetrics; it embraced paediatrics and psychiatry-then called by simpler names; it necessitated dispensing one's own medicaments; it meant travelling often up to thirty or forty miles in a day by horse and trap and, in later times, by primitive (but much prized and admired) motor-car; it was strenuous, comprehensive and entirely satisfying. It was the 'middle-ages' of the relatively short history of medicine in New Zealand and coincided with the transition from Colony to self-governing Dominion.

It is only 126 years since in 1840 New Zealand was officially annexed by the British Crown following the Treaty of Waitangi between the indigenous population-the Maoris-and Queen Victoria. But many years before the official establishment of a Colony, much-medically and otherwise-had been happening in New Zealand. The very name 'New Zealand' reminds one that the first man to see the country-he did not land - sent by the Netherlands East Indies Company in 1642, was the Dutchman Abel Tasman.

The first medical man to set foot on New Zealand soil was Monkhouse-Captain Cook's surgeon in the Endeavour in 1769. Cook made a detailed study of the New Zealand coastline and had many contacts with the natives.

The Maoris undoubtedly had a primitive medicine of their own-a potent and practical mixture of psychology and pharmacology. It was practised by the witch doctors or 'tohungas' whose knowledge of local herbs was considerable and who were also very reasonable surgeons-this latter skill perhaps not entirely unrelated to the fact that, in pre-colonisation days, the Maoris were cannibals! There is, however, ample proof that, using knives of obsidian (a volcanic glass) they opened abscesses and removed neck glands. They also were adept at setting fractures.

The Maoris believed that all diseases were due to the machinations of evil spirits 'atua' and were visited upon them as a result of eating foods and performing actions which, according to tribal custom, were 'tabu' or forbidden. There seems reason to believe that the Maoris derive from a far greater distance than the Cook Island groupwhich is usually accepted as their origin. They possess characteristics, both physical and mental, which suggest that Polynesia was perhaps only the last stopping place on a trek that might extend backwards in history through Malaysia, the Indian subcontinent even to Arabia and the Mediterranean basin. Dr. Peter Buck, himself a 


\section{The History of Medicine in New Zealand}

Maori and well-known medical man and anthropologist, believes that the present Maori as we know him has existed in New Zealand for something approaching ten centuries and that he was preceded by a race of 'Moa-hunters' in the so-called Archaic Period. Be all this as it may, there is no doubt the Maoris collected for themselves a very valuable formulary of native flora. Included in this may be mentioned the juice of the 'aka' (or white creeping 'rata') containing tannin which was blown on to a wound or bleeding surface through six-inch bamboo shoots as a haemostatic. It was also used as an infusion for coughs and colds. Other valuable haemostatics were 'panara'-a type of groundsel-prepared by chewing its leaves or flowers; the bruised and beaten leaves of 'kohu-kohu'-a swampy moss; and the bark of the 'rewarewa' tree.

A frequently used and highly successful concoction for agues (fevers) consisted of the root of the native flax, again kohu-kohu leaves and matoutou leaves, boiled together, strained and given in doses of one 'pana' shell (a native shell-fish) fullapproximately two tablespoonfuls twice a day.

Bruises and abrasions were treated by a concoction of kawa-kawa root-the pepper tree-the chewing of which was also recommended for toothache-suggesting in both cases a natural counter-irritant. The buds of the 'koromiko'-a genus of veronica, made into an infusion by steam distillation, were used for diarrhoea as was fern-root and charcoal. The gum of the great 'rimu' trees proved efficacious for haemoptysis and obviously the natural hot sulphur-springs were used for various skin diseases. Just to show how little new there is in the world, scarification by obsidian, tapôtement by small sticks and a concoction of 'pukatea' (laurel) bark, were all in frequent use for pains, neuralgias, vague aches and rheumatism. When the white man's arrival brought firearms, gun-shot wounds became prevalent and the Maori surgeons became adept at removing the balls but, if they failed, they plugged the wound with wet clay and covered it with an astringent dressing of 'karaka' leaves.

With the whalers and sealers, traders and missionaries, who sporadically followed Captain Cook, and with the colonists who started permanent settlements in the early nineteenth century, came, as well as new methods of medical treatment (often little better than the older native therapeutics) new diseases (at first in particular measles) to plague and decimate the Maoris. Add to these the wounds and injuries of the Maori Wars-chiefly fought over disputed land tenure-which followed in the middle of the century the signing of the Treaty of Waitangi (1846) and it is not surprising to find that, at the turn of the century, the Maori race was in dire peril of being wiped out. An estimate-and probably a very rough underestimate-of the Maori population at the time of Captain Cook's visit was 150,000. The first official census of 1858 showed this figure reduced to 56,000 and it sunk to an all-time low in 1898 when the native population was a mere 42,000 . Since then, however, an extraordinary recovery has taken place. In 1920, the Maoris numbered 57,000; in 1960, 157,000 and, today, $207,752,7 \%$ of the total population. The reasons for this surprising reversal of trend are complex and varied. The very genuine amity that has grown up between 'Pakeha' (white man) and Maori has produced an entirely peaceful environment; undoubtedly, the Maori has acquired some natural resistance over the years to the white man's diseases which, at first, so sorely afflicted him; he has accepted 
easily and happily the white man's way of life and is blandly indifferent to economic conditions; he marries early and his fertility is great and he is, to date, quite without interest in anything resembling family planning or control! Given a continuance of these conditions, the Maori may well produce one of the classical examples of population explosion yet seen in the world. At the present rate of progress, five million Maoris by A.D. 2,000 is no impossibility!

Since hospitals were first instituted in New Zealand (in Wellington, Wanganui, New Plymouth and Taranaki in 1846, Auckland in 1847, Dunedin in 1851 and Christchurch-Lyttleton 1853) 'for sick and destitute Europeans and the free treatment of all Maoris', the latter have accepted admission and treatment easily and happily. They share wards, both large and small, and have equal facilities with their white brethren and have proved themselves excellent patients-brave, cheerful and co-operative. Their admission rate exceeds that of the white patient in all diseases except appendicitis (this applies particularly in the female, where it is very rare), peptic ulceration, gall-bladder disease, enlarged tonsils, enlarged prostate and psychiatric disease. Certain disease patterns have become obvious over the years, one of the more interesting being the prevalence of cardiac disease in the Maori-particularly the Maori woman. In the latter, coronary thrombosis and essential hypertension are of everyday occurrence-a lazy way of life and the tendency to overweight being probably important factors. The great scourge of the Maoris in early days was, of course, tuberculosis. It is always stated that this was introduced by the white man but there is authenticated record of a very similar wasting disease called 'Mata Kohi' being in existence in pre-colonization days. Be that as it may, there is no doubt that, for the first hundred years of New Zealand's history, tuberculosis ran wild amongst the native population and produced a fearsome mortality. Today the flame has died down to negligible proportions.

Certain other tendencies in disease incidence that have come to light are perhaps worthy of notice. All Maoris are rhesus negative; a very high proportion of them are Group A. They, in fact, show, with the North American Indian, the highest incidence in the world. For this reason the Maori produces a relatively large number of cases of diabetes mellitus, gastric carcinoma, pernicious anaemia and carcinoma of the female genitalia. The incidence of rheumatoid arthritis is low but cases of gout are frequent; rheumatic fever and dysentery both have high incidence. One particularly interesting fact is the preponderance in Maori women of both bronchiogenic carcinoma and of aneurysms of both the abdominal aorta and the smaller cardiac vessels ('berry' aneurysms). Suicide rates are approximately equal in both the Maori and the white population.

Leaving the Maoris and reverting to medicine and medical men in the early days of colonization, one meets many examples of sturdy individualism concerned chiefly with the activities of the 'New Zealand Company'-a body set up to promote emigration to the new colony. Its founder in 1839 was Edward Gibbon Wakefield. Aboard each of the ships the company chartered were a number of medical men- the progenitors of New Zealand medicine. New Zealand Company surgeons received ten shillings for every passenger payable in New Zealand, five shillings for every child aboard between the ages of seven and fourteen and 3s. $6 \mathrm{~d}$. for every infant from birth 


\section{The History of Medicine in New Zealand}

to the age of seven; $£ 1$ was deducted for every death aboard but $£ 1$ was added for every birth and a bonus of $£ 50$ was usually granted at the end of a successful trip. These men then settled down in various parts of New Zealand to practise the rugged medicine that the primitive conditions of the country at that time demanded. Two typical examples may be quoted, the settlements in Taranaki and Otago, which later became respectively New Plymouth and Dunedin.

The Tory, a ship of 382 tons, made the remarkable passage to Taranaki of 96 days and carried in its complement, as well as the ship's surgeon, George Robinson, two other doctors, John Dorset, who actually effected the purchase of Taranaki for the New Zealand Company from the Maoris, and Ernest Diefenbach, an M.D. of Berlin, who apart from his practice has to his credit the first ascent of Mt. Egmont. These men became key figures in the new community and their activities extended far beyond the realms of medicine.

An even earlier medical visitor to Taranaki was a certain Dr. Marshall, the surgeon of H.M.S. Alligator, which, in 1834, was sent on a punitive expedition to rescue the survivors of a whaler's wreck (the master's wife and three children). The whaler's crew had all been massacred by the Maoris and, in a brush between the natives and the Alligator's men, the local chief was captured and badly wounded. Dr. Marshall comments on the latter's remarkable powers of recuperation due to, as he puts it, 'the absence of infection and a physique unweakened by excess of food and liquor'.

In Dunedin, the first and to this day the principal medical centre in New Zealand, development started in 1848 following the purchase in 1844 by Wakefield and the New Zealand Company of some 40,000 acres of land from the Maoris. Previous to this, Dunedin, or Otepoti as it was originally called, was populated by two runaway sailors! The arrival of the two ships John Wickliffe and Philip Loring boosted the population at the end of 1848 to 450 souls - the new emigrants being largely Free Church dissidents from the Church of Scotland.

Previous to this settlement, the only doctor in Otago had been a certain Joseph Croome who, from 1836 had attended the widely spread small population of various whaling stations on the coast. Croome, born in Bath in 1811, the son of a West Indian planter, was a pupil of Sir Astley Cooper and Sir William Blizzard and qualified as a Licentiate of the Royal College of Surgeons in 1833. His work in Otago can only be described as prodigious and has now become legendary. His practice extended over a vast area; journeys of 50 to 100 miles a day were commonplace and were carried out initially on a riding bullock or in a rowing boat until horses became available. Not infrequently, they had to be completed on foot with a Maori guide and rivers crossed by improvised raft. Such journeys more often than not necessitated staying, often for some days, with his isolated groups of patients. He was, in essence, a real family doctor.

With the 1848 settlement came three more doctors-Manning, Williams and Purdie-and these gave medical cover to a population which had risen to 2,000 by the end of 1860 . Their living was chiefly made in kind-a monetary recompense of $£ 40-£ 50$ per annum being an average income.

In 1861 came the Gold Rush to Central Otago and, with it, a sudden increase in population, up to 30,000 in 1863 , and a corresponding rise in the number of doctors- 
Sir Arthur Porritt, Bt.

up to 15 by 1862 and double this number two years later when a veritable 'Harley Street' had been established in Princes Street, Dunedin. This team coped with the usual troubles of a gold-rush town-a town largely established in marshy land; a town with the most primitive sanitation; a town with a transient, profligate and riffraff population. It is not surprising therefore that so-called 'marsh fever' (probably typhoid), dysentery, diphtheria, scarlet fever and venereal disease were rife. These, together with many wounds from mining accidents and gold fever fracas, had to be coped with in the absence of antiseptics or anaesthetics-even very often without stethoscopes or clinical thermometers.

Amongst the personalities of these hectic days one or two seem to demand mention. Alfred Eccles, a graduate of St. Bartholomew's and a Fellow of the Royal College of Surgeons in 1858, came to Dunedin in 1862 and had much to do with cleaning up the abysmal sanitary condition of the gold-rush city. But, apart from this, and as an example of the large part early medical men played in local affairs, he was the author of New Zealand's first national exhibition (1865); he was active in the formation of the New Zealand Institute, later to become the New Zealand Royal Society; he promoted the New Zealand Acclimatization Society (to protect trout in local rivers) and loosed the first brace of pheasants in New Zealand and he advocated at this early stage the use of New Zealand's ample water supplies from rivers and falls, for the production of electricity.

The buildings used for the New Zealand Exhibition became the following year (1866) Dunedin's first hospital. How primitive this institution was is evidenced by the fact that it had no heating and an Otago winter is quite rigorous; its baths consisted of tubs behind screens; its matron had no nursing training and its nurses consisted of convalescent patients and casual labour from the neighbouring streets. The first surgeon appointed to this hospital was a doctor with the well-known name of Robert Burns-not surprisingly a Fellow of the Edinburgh College-who had come to Dunedin in 1858. Apart from being a skilful all-round doctor, Burns was no mean scholar and a first class cricketer.

Another medical cricketer and athlete who deserves mention was Dr. Duncan McGregor, who qualified in Edinburgh in 1870 and came to New Zealand the following year as the first Professor of Mental Science in the newly-formed Otago University (1869). It was he who introduced Listerian antiseptic surgery into New Zealand when he treated (and successfully) in 1:40 carbolic lint the arm of a workman pulped from wrist to above elbow in a flax-scratching machine.

Whilst these sporadic and entirely praiseworthy isolated islands of medical activity were at work in various parts of the new colony, the administration of the day was beginning to take an active interest in regularizing medical practice. As early as 1849 the Legislative Council of New Munster (which consisted of the South Island and the Southern third of the North Island) achieved a degree of medical registration. The then Colonial Secretary (Alfred Domett) brought in the so-called 'Medical Practitioners Bill' on $8 \mathrm{May}$; it obtained its first reading on the 9th and was passed on the 18th and received the Queen's consent in 1850 -eight years before the United Kingdom followed suit! This early Act provided for the issue of a certificate of registration on the production of a diploma of qualification and the payment of a fee-and the 


\section{The History of Medicine in New Zealand}

certificate allowed the holder to charge a coroner's fee and gave him exemption from Jury Service. Unfortunately, in 1853, New Munster and its ordinances were abolished and the four provinces of Auckland, Wellington, Canterbury and Otago set up. It was 1860 before the 'Medical Practitioners Bill' again came before the Legislative Council. Brought forward by a Dr. Menzies 'to effect public guarantee of proper qualification of medical practitioners', it met with unexpected opposition chiefly through Sir Osborne Gibbs, who championed the cause of the homeopaths, who were particularly strong in Auckland.

The Bill was described as 'exclusive' and 'arbitrary' and much support came forward for the 'globules of homeopathic remedies'. Despite support from David Monro, one of the famous Edinburgh family of anatomists, the Bill lapsed and was not resuscitated until seven years later.

In 1867, with Monro, now Sir David and Speaker of the House, a Bill was introduced by the new Postmaster General (Hall) to 'extend the law of the United Kingdom in respect of medical registration to the Colony'. The only real opposition to this came from the fear that a simultaneous adoption of the British Pharmacopoeia might exclude the therapeutic use of certain valuable indigenous remedies. Nevertheless, the Bill was duly passed in September 1867 and received the Governor's (Sir George Gray) assent the following month.

Dr. James Hector, M.D. (Ed.) and F.R.S., was appointed President of the first Medical Board - a body corresponding to our General Medical Council-which has continued to function ever since and celebrates its centenary next year. The members of today's Council are the nominees of the Governor-General and certain ex-officio members-the Dean of the Otago Medical School, the Director-General of Health and a representative of the New Zealand Branch of the British Medical Association.

In passing, it may be noted that the New Zealand Branch of the British Medical Association is now some 70 years old and is one of the very few overseas branches of any size not to have claimed independence. It was formed originally owing to the failure of an early New Zealand Medical Association to establish itself. Indications are that, before very long, the New Zealand Branch of the British Medical Association may revert to the new Zealand Medical Association!

No account, however brief, of New Zealand's medical history would be complete without some description of the Otago Medical School-New Zealand's first and, to this day, only medical school.

Dunedin as a Scottish settlement obviously would have amongst its prime ideals and objectives the furtherance of both religion and education. This, to the pioneers, meant a University as soon as possible and this they achieved in 1869, when the Provincial Court established Otago University on predesignated land. The new university was given the right to confer degrees in Art, Theology, Music and Medicine. The first Chancellor was the Revd. Thomas Burns, nephew of the poet. Given the establishment of the university and in view of the fact that Dunedin had then the biggest hospital in New Zealand ( 200 beds as compared with Auckland's 77 ) it was obviously the right place to institute the first medical school.

The embryonic stage of this was the appointment of Dr. Coughtrey as Professor of Anatomy and Physiology in 1874. It is of interest to note that one of the unsuccessful 


\section{Sir Arthur Porritt, Bt.}

candidates for this post was the same Cunningham as is so well known to all of us as, at a later date, Professor of Anatomy in Edinburgh. Coughtrey's task proved frustrating in the extreme. Only a two-year course was planned at first-the students being sent to Scottish and English schools to complete their clinical work. As only Edinburgh, Trinity College, Dublin, and the Royal College of Surgeons, England, would give recognition to this New Zealand pre-clinical course, and as an 'Anatomy Act' permitting the use of bodies for dissection was not passed until 1875 and as Coughtrey's whole-time salary was only $f 600$ per annum it is not surprising that he resigned in 1876 and took up private practice in Dunedin.

He was succeeded by John Halliday Scott whose appointment coincided with that of the first lecturers in Medicine and Surgery-at $£ 100$ per annum each!

In 1882, a full medical course of four years was approved and, in 1885, it became effective. It was essentially a hospital rather than a university medical school, and its teachers were, at that time, exclusively vocational, i.e. part-time clinical.

In 1891, a Faculty of Medicine was officially established in the university with Halliday Scott as the first Dean and Coughtrey as Sub-Dean. It is worthy of note that, in the whole history of the school, there have been only four Deans-Scott continued until 1914, when Sir Lindo Ferguson, an ophthalmologist, took over until 1936. It was during his term of office that the first medical school as a building (costing $£ 20,000$ ) was opened in 1917. From 1937 to 1958, Sir Charles Hercus held the reins and the present Dean-Sir Edward Sayers-is well known to many here-not only as a recent President of the Royal Australasian College of Physicians.

The Otago School still remains essentially an undergraduate institution-although, of recent years, post-graduate activities and research facilities have developed under the aegis of full-term clinical chairs. The school now produces approximately 100 doctors a year from an annual intake of 120 -half the number of applicants. The relative lack of interest in engineering and technology in New Zealand to date has probably been an important indirect cause of medicine's being so popular as a career.

The first graduate of the school was W. L. Christie in 1887 who, like so many other New Zealand graduates, ultimately practised elsewhere-in Bristol, Sarawak and Harwich! The first female graduate was Dr. E. H. McKinnon in 1896-women having equal rights and privileges in the school from its inception. The first Maori graduate was Sir Maui Pomare in 1899, who was two years later given the task of supervising the care of Maori Health and who ultimately became Minister of Health in the Dominion Parliament.

One other early medical student surely deserves mention-Sir Louis Barnett. After his preliminary two years in Otago (1883/4) he completed his medical training at Edinburgh and, in 1890, became the first New Zealander to obtain the English F.R.C.S. by examination. In 1894, he was appointed Lecturer in Surgery at Otago; became the first (part-time) Professor of Surgery in 1909 and continued in this post until he handed over to Sir Gordon Bell in 1924. His chief interest lay in hydatid disease-relatively so prevalent in New Zealand and, among other claims to fame, he was the first New Zealander to visit the Mayo Clinic (1904), the first to wear a mask and gloves as a routine in the operating theatre (1905) and an instigator of the foundation of the Royal Australasian College of Surgeons in 1927, of which he was the first 


\section{The History of Medicine in New Zealand}

Vice-President and subsequently in 1937/8 the President.

New Zealand has always been health-conscious. It has had a Ministry of Health since 1900 , as compared to the 1919 of this country. This atmosphere was probably engendered in the early colonists by a natural reaction to the conditions they had left behind in Victorian Britain. As a result, policies in New Zealand have for years tended to be liberal in outlook and equalitarian in ideal. The conception of a welfare-state, even if not called by that name, took root very early in New Zealand's history. It was the first country to give votes to women in 1893; the massive enactment in respect of old-age pensions first instituted in 1898 still constitutes a major load on the annual budget; Health Acts were passed by the legislature as early as 1872 and 1876 establishing a Central Board to control the public health of the Colony and the 1900 Act instituted a Ministry (and a Minister) which has steadily increased its sphere of influence-and its expenditure!- ever since. The cost to the country was $£ 40$ million in $1958(15 \%$ of the national budget as compared with the United Kingdom's $10.5 \%$ and U.S.S.R.'s $6.5 \%$-today it is nearer $f 60$ million!

In child welfare New Zealand has been for long an acknowledged leader in world medicine and, in this respect, the name of Truby King will always merit remembrance. Truby King-yet another Edinburgh graduate-lived for 80 fruitful years (18581938) and was a pioneer in the care and dietetic control of children. He established the famous Plunkett Society to fulfill these purposes in 1907 and its activities were markedly enhanced by the establishment of Plunkett Training Centres throughout the country in 1918. The foundation of the Society was commemorated by a special postage stamp in 1957. Incidentally, in this respect, it is worthy of note that, since 1931, New Zealand has issued special Health Stamps annually, carrying an additional 'charity' surcharge.

In 1920, the School Dental Service was instituted, providing free treatment for all school children up to the age of sixteen. This treatment is carried out by specially trained dental nurses. The use of nursing personnel was at first bitterly opposed by the dental profession, both in New Zealand and elsewhere but, over the years, the system has more than proved its efficiency in saving both teeth at a critical stage of development and dental manpower which remains woefully insufficient in most countries of the world.

In 1937, the Health Department set up a Medical Research Committee which, in 1950, matured into the New Zealand Medical Research Council, which currently costs the country an approximate $£ 150,000$ a year $-25 \%$ of the Health Service expenditure.

And so we come to New Zealand's now famous Social Security Act of 1938a large part of which was concerned with the State Medical Service. Before a brief consideration of the inception and details of this Service-New Zealand's medicine of today-it is pertinent to remember the State which employs the Service.

New Zealand itself has surely many attributes which ensure a high standard of health. It has a temperate climate with ample sunshine; there is no overcrowding and virtually no slums; most people live an essentially outdoor life with plenty of fresh air; food is ample and good; facilities for recreation, both physical and mental, are readily available and the time for it has steadily increased pari passu with the rise in the standard of living; the people come from a virile stock. It is all the more 
surprising, therefore, to find that New Zealand's birth-rate is not particularly high, whilst its sterility and abortion rates are; that dental caries is rife; that the suicide rate is high and that it possesses a relatively unenviable number of large mental institutions.

It is against this background that the New Zealand State medical service was introduced, despite its being an obvious political measure with the best of idealistic socialist motives. It was to prove the lynch-pin of the perfect welfare state! Sadly, it was of hasty conception and planned without any consultation with the medical profession; the introduction of its various parts has, over the years, been haphazard and, for economic reasons, it still remains to this day incomplete. As a pilot experiment in state health services, its importance cannot be over-rated, but the attention paid to the experiment has varied from considerable to virtually nil in different countries in the world-and most countries now appear to be fully convinced that some sort of national health service is an essential prestige symbol. One would have hoped that the inevitable faults in and difficulties of the New Zealand Service might have proved of greater value than they have to others.

The Service was initiated in April 1939 with the provision of mental hospital treatment-a fact perhaps worthy of notice! There are ten mental hospitals, three hospitals and training schools for mentally sub-normal children and one hospital for functional nervous disease-an overall coverage of five beds per 1,000 of population. Next followed in July 1939 provision of free hospital treatment; 85\% of hospital beds are government controlled, the remaining $15 \%$ being in private nursing homes. There are no pay-beds or private wings in the state hospitals (but overseas visitors pay a charge of $£ 4$ per day!).

The hospitals are frankly overcrowded, overworked and under-staffed. All finance comes from Government grants and these come to more than $£ 20$ million per annum. It is in respect of hospital staffing that the Service shows its greatest hiatus. There are relatively very few whole-time appointments (especially clinical) and the part-time staff are paid so poorly for their services, both in relation to corresponding posts in other countries and to the value of money today, that the temptation to earn-in fact the necessity of earning - a living outside the hospital in private practice is irresistible. As Douglas Robb states-'Specialists earn three-fifths of their living on an island of private practice surrounded by an ocean of social security'.

This inability of the Government to provide adequately remunerated consultant and specialist services, thirty years after the inception of the service, is undoubtedly the greatest obvious failure of the whole scheme. The tendency to cater for quantity rather than quality is underlined again by the fact that teaching hospitals, both undergraduate and post-graduate, receive no special consideration in the allocation of the grant monies. The addition of free out-patient treatment in the hospitals which came in 1941 did little but show up the all-too-obvious inadequacy of facilities in out-of-date hospitals-and increase the bill!

In 1939 also came the third Benefit-Maternity Services-and, to give credit where credit is due, these have proved to be efficient, easily workable and much appreciated. Most women have their confinements in hospital, the doctor receiving a fee of $£ 88 \mathrm{~s}$. $0 \mathrm{~d}$. but, where the delivery takes place at home or in a private nursing home, this grant is deductible. To date, obstetrics and gynaecology have certainly 


\section{The History of Medicine in New Zealand}

made the best provision for post-graduate training and research facilities. This is evidenced by the excellent post-graduate centre now established in Auckland.

After a pause for thought, in 1941, came the introduction of Pharmaceutical Benefits-with their inevitable appeal to the public and the politician, and their everincreasing cost-and the setting up of the General Practitioner Service. This latter, geared to a fee-for-service remuneration basis, has after early teething troubles proved itself workable and generally acceptable, both to the doctor and his patients. There is no doubt that the New Zealand general practitioner is a good all-round doctor-often with higher qualifications, and it is right that, in an essentially rural population, the family doctor should be given as much support as possible. It is rather sad that this has been achieved to the financial detriment of the specialist-and it is also an extraordinary fact that the Government grant to the doctor (7s. $6 \mathrm{~d}$. per head per attendance, to which he can add a personal fee as and when deemed reasonable) has remained unchanged during the 25 years the scheme has been working!

After this, supplementary benefits were included in the Health Service at sporadic intervals. In 1942, a 50\% grant to cover diagnostic radiological fees was institutedbut it should perhaps be pointed out that these fees are themselves only about $50 \%$ of those obtaining in the United Kingdom and U.S.A. Laboratory facilities are provided entirely free, whether the patient is private or not, and these include blood transfusion. In Physiotherapy, the state grant covers one-third of the fee, and help is given in District Nursing. In 1947, a Dental Service was provided, over and above the School Dental Nursing Service already mentioned. This again is on a fee-for-service basis and has been accepted by $75 \%$ of the dental profession and $90 \%$ of the population. In this discipline also one notices no particular consideration being given to teaching institutions or research.

Such is New Zealand medicine today. The high cost of the Health Serviceadmittedly incomplete after nearly thirty years-together with the vast expenditure on Pensions-gives New Zealand the highest taxation rate in the world! Again, to quote Robb 'Taking an unbiassed view of the overall situation, the New Zealander seems to be getting too little for too much!'

We should always be grateful to New Zealand for their bold experiment in 1939but equally we and they should be broadminded enough to learn from the faults and failings shown up by the intervening years. Modern medicine being what it is, no country can afford a State Service that is a monopoly-if standards are to be maintained-and advanced. These standards can never be adequately judged by either public or politician and their complacency in accepting a status quo is one of the most insidious influences the profession must continue to fight-both in New Zealand and elswhere. Because the New Zealand Health Service Scheme has continued longer than any other, it allows more perspective-and perspective is vital. In 1954, in an address to the Royal Society of Arts, I made the following statement-and, sadly, in the intervening years, the proved immiscibility of politics and medicine have not allowed me to change my opinion:-

All the schemes embody ideological principles which none would question; all of them contain, and already exemplify, glaring defects which should be capable of correction. The tendency to underline the latter comes only from a very real fear that already a generation is growing up- 


\section{Sir Arthur Porritt, Bt.}

professional, political and public - in which old values are tending to be forgotten; and to those of us who were brought up in those older traditions, however broadminded and up to date may be our present outlook, there is much that any thinking doctor knows he just cannot afford to give up. A profession as old as Medicine will not forcibly be revolutionized to anyone's advantage by a few short years of immature political control. The experiment must go on but it is essential for its ultimate success that the most broadminded co-operation should be developed between those most concerned; the patient as represented by governmental authority (as it is the State purse which ultimately in part or in whole has to pay) and the doctors. The problem to be solved is at basis the efficient and friendly integration of the age-old tradition of medicine with the economic state of the world today.

The solution has not yet been found; it will not be found tomorrow. Like all worthy experiments, it will demand much thought, infinite patience, general goodwill and intense work. Given these and a moral and philosophical outlook (sadly lacking at the moment) there would seem to be no cogent reason why, in the all encompassing course of time, an achievement really worthy of humanity at its best should not ensue. 